\title{
Potensi Probiotik Terhadap Feed Efficiency dan Egg Mass pada Ayam Petelur
}

\author{
Potency of Probiotics on Feed Efficiency and Egg Mass in Laying Hens
}

\author{
Khasmawati Mas'ad ${ }^{1 *}$, Widya Paramita Lokapirnasari², Moh. Anam Al Arif ${ }^{2}$, \\ Soeharsono $^{3}$, Rochmah Kurnijasanti ${ }^{4}$, Nenny Harijani ${ }^{5}$ \\ ${ }^{1}$ Magister of Veterinary Agribusiness, ${ }^{2}$ Department of Animal Husbandry, ${ }^{3}$ Department of Veterinary Anatomy, \\ ${ }^{4}$ Department of Veterinary Basic Medicine, ${ }^{5}$ Department of Veterinary Public Health, \\ Faculty of Veterinary Medicine, Universitas Airlangga, \\ Jl. Mulyorejo, Kampus C, Universitas Airlangga, Surabaya, Indonesia 60115 Telpon 031-5992785 \\ *Corresponding author: khasmasad@gmail.com
}

\begin{abstract}
Abstrak
Tujuan dari penelitian ini adalah untuk mengetahui penggunaan probiotik yang mengandung Enterobacter sp., Cellulomonas sp., Actinomyces sp., Bacillus sp., dan Lactobacillus sp. terhadap feed efficiency dan egg mass pada Ayam Petelur. Sebanyak 36 ekor ayam petelur umur 30 minggu yang terdiri dari 3 perlakuan. Perlakuan terdiri dari P0 (tanpa probiotik), P1 (probiotik $1 \mathrm{ml} / \mathrm{liter}$ ), P2 (probiotik 2 ml/liter). Hasil penelitian pemberian probiotik berpengaruh $(\mathrm{p}<0.05)$ terhadap feed efficiency dan egg mass. Pemberian probiotik sebanyak $2 \mathrm{ml} /$ liter air minum (P2) menunjukkan nilai feed efficiency tertinggi $\left(66.1^{\mathrm{b}} \pm 3.29\right)$. Nilai egg mass tertinggi $\left(51.9^{\mathrm{b}} \pm 3.36\right)$ terdapat pada $\mathrm{P} 1$ yaitu perlakuan yang diberi probiotik sebanyak $1 \mathrm{ml} /$ liter air minum. Dapat disimpulkan bahwa pemberian probiotik dengan dosis $1 \mathrm{ml} / \mathrm{liter}(\mathrm{P} 1)$ maupun dosis $2 \mathrm{ml} / \mathrm{liter}$ (P2) meningkatkan feed efficiency dan egg mass.
\end{abstract}

Kata kunci: probiotik, feed efficiency, egg mass

\section{Abstract}

The purpose of this study was to determine the use of probiotics containing Enterobacter sp., Cellulomonas sp., Actinomyces sp., Bacillus sp., and Lactobacillus sp. on feed efficiency and egg mass in layer. A total of 36 layers at 30 weeks age consisting of 3 treatment, respectively. The treatments consisted of PO (without treatment), $P 1$ (probiotics $1 \mathrm{ml} /$ liter), $P 2$ (probiotics $2 \mathrm{ml} /$ liter). The results showed that probiotics had an effect $(p<0.05)$ on feed efficiency and egg mass. The administration of probiotics dose of $2 \mathrm{ml} / \mathrm{liter}$ in drinking water (P2) showed the highest value of feed efficiency $\left(66.1^{b} \pm 3.29\right)$. The highest egg mass value (51.9 ${ }^{b}$ $\pm 3.36)$ showed at P1 treatment administered dose of $1 \mathrm{ml} /$ liter in drinking water. It can be concluded that the administration of probiotics with a dose of $1 \mathrm{ml} /$ iter $(P 1)$ and a dose of $2 \mathrm{ml} / \mathrm{liter}(P 2)$ improve feed efficiency and egg mass.

Keywords: probiotics, feed efficiency, egg mass

Received: 15 Januari 2020

Revised: 19 Januari 2020

Accepted: 14 Februari 2020

\section{PENDAHULUAN}

Tingkat konsumsi protein hewani masyarakat Indonesia tahun 2018 untuk daging ayam dan telur lebih tinggi bila dibandingkan konsumsi daging sapi. Tingkat konsumsi telur ayam tahun 2018 sebesar $6.53 \mathrm{~kg} / \mathrm{kapita} / \mathrm{tahun}$ (125 butir/kapita/tahun) (BPS, 2018). Tingkat konsumsi telur ayam oleh masyarakat Indonesia sudah tinggi, namun tidak diimbangi kenaikan populasi dan produksi ayam petelur itu sendiri. Kendala dalam pemeliharaan ayam petelur adalah fluktuasi harga pakan yang tidak menentu. Keberhasilan usaha ayam petelur yang dipelihara secara intensif sangat tergantung pada ketersediaan bahan pakan murah dan mampu memenuhi kebutuhan zat nutrisi ayam petelur. Metode yang dapat digunakan untuk meningkatkan nilai kegunaan pakan adalah melalui feed additive (Diarmita, 2019). 
Beberapa feed additive seperti hormon Antibiotic Growth Promotor (AGP) telah dilarang penggunaannya. Pelarangan penggunaan AGP dan antikoksi sebagai imbuhan pakan sesuai dengan amanat Pasal 22 ayat 4c UU No 18/2009 juncto No 41/2014 tentang Peternakan Kesehatan Hewan, Terkait pelarangan AGP, alternatif untuk tetap membuat performa ayam menjadi baik, yaitu dengan penggunaan probiotik (Dimyati, 2018).

Penggunaan probiotik dapat berpengaruh terhadap feed efficiency dan egg mass. Pernyataan tersebut sesuai dengan kinerja probiotik yaitu menstabilkan mikroflora pencernaan (Gallazzi et al., 2016). Penggunaan probiotik di kalangan peternak ayam telah banyak dilakukan karena mempunyai berbagai fungsi, antara lain mampu meningkatkan pertumbuhan dan efisiensi pakan, mencegah radang usus, meningkatkan produksi telur dan memperbaiki kualitas telur (Hartono dan Kurtini, 2017).

Penelitian tentang penggunaan kombinasi probiotik Enterobacter sp., Callulomonas sp., Actinomyces sp., Bacillus sp., dan Lactobacillus $s p$. adalah kombinasi bakteri selulolitik dan Bakteri Asam Laktat (BAL). Bakteri asam laktat memiliki enzim $\beta$-glukosidase ( $\beta$-Glu), $\beta$ galactosidase ( $\beta$-Gal) dan enzim yang dapat menghidrolisis laktosa. Karakteristik yang mendefinisikan bakteri asam laktat adalah toleran terhadap kondisi asam dan garam empedu dan menghambat pertumbuhan bakteri patogen dengan cara menciptakan kondisi asam, garam empedu beracun bagi sel, dan cenderung merusak struktur membran sel. Probiotik tahan terhadap garam empedu dan kondisi asam berkontribusi terhadap kemampuan untuk menahan kondisi yang ekstrim di GIT (Lokapirnasari et al., 2018). Selulase adalah enzim yang diproduksi oleh mikroba selulolitik yang mampu menghidrolisis ikatan $\beta-1,4$ glikosida dalam selulosa, struktur polisakarida sering ditemukan pada tanaman (Lokapirnasari dkk., 2015). Penggunaan bakteri selulolitik (Cellulomonas sp.) dapat menurunkan serat kasar. Pemberian probiotik selulolitik dapat membantu dalam mencerna dan penyerapan zat gizi serta menekan mikroba yang tidak menguntungkan (patogen), sehingga efektifitas enzim dan efisiensi pakan akan lebih menguntungkan secara keseluruhan (Ronstarci et al., 2015). Penelitian ini bertujuan mengetahui pengaruh probiotik yang mengandung Enterobacter sp., Callulomonas sp., Actinomyces sp., Bacillus sp., dan Lactobacillus sp. terhadap feed efficiency dan egg mass pada ayam petelur.

\section{METODE PENELITIAN}

Persetujuan laik etik dari komisi etik penelitian Universitas Brawijaya No: 1136-KEPUB. Penelitian dilaksanakan di peternakan rakyat Desa Talun Kecamatan Montong Kabupaten Tuban pada pada bulan Mei - Juni 2019. Materi yang digunakan dalam penelitian ini adalah ayam petelur umur 30 minggu, probiotik yang mengandung Enterobacter $s p$., Cellulomonas sp., Actinomyces sp., Bacillus sp., dan Lactobacillus sp., dengan konsentrasi $1.2 \times 10^{9} \mathrm{CFU} / \mathrm{ml}$.

Jenis penelitian ini adalah penelitian eksperimental. Rancangan yang digunakan dalam penelitian ini adalah rancangan acak lengkap. Penelitian dilakukan selama (28 hari). Penelitian ini menggunakan 36 ekor ayam petelur. Terdiri dari 3 perlakuan, Masingmasing perlakuan berisi 12 ekor ayam petelur. Perlakuan terdiri dari (P0) tanpa probiotik, (P1) probiotik dosis $1 \mathrm{ml} / \mathrm{liter}$ air minum, (P2) probiotik dosis $2 \mathrm{ml} /$ liter air minum.

Cara pemberian probiotik yaitu melalui air minum pada pagi hari pukul 07.00 WIB. Pemberian probiotik melalui air minum memiliki hasil yang lebih optimal dari pada pemberian probiotik melalui pakan (Lokapirnasari et al., 2018). Larutan probiotik tersebut dicampurkan ke dalam air minum, kemudian diaduk secara merata dan air minum siap diberikan. Pembuatan larutan probiotik dilakukan setiap hari dan pencampuran dengan air minum dilakukan setiap akan memberikan air minum.

Pengambilan data feed efficiency dan egg mass dimulai dari minggu ke 3 sampai minggu ke 4 penelitian. Data yang didapat dari hasil penelitian, diolah dengan menggunakan bantuan 
microsoft excel. Data hasil feed efficiency dan egg mass dianalisis statistik menggunakan analysis of variance (ANOVA). Apabila diperoleh hasil yang berbeda nyata $(p<0.05)$ maka dilanjutkan dengan Uji Duncan.

\section{HASIL DAN PEMBAHASAN}

Berdasarkan Tabel 1. pemberian probiotik berpengaruh terhadap feed efficiency dan egg mass. Berdasarkan hasil feed efficiency, pemberian probiotik berbeda nyata $(\mathrm{p}<0.05)$ dengan perlakuan P0. Hasil pemberian probiotik sebanyak $2 \mathrm{ml} /$ liter air minum (P2) menunjukkan nilai efisiensi pakan tertinggi $\left(66.1^{\mathrm{b}} \pm 3.29\right)$, sedangkan nilai efisiensi pakan terendah terjadi pada perlakuan yang tidak diberi probiotik (P0) (Gambar 1).

Efisiensi pakan dapat digunakan untuk melihat peningkatan penyerapan nutrisi dan proses metabolisme energi. Peningkatan efisiensi pakan memiliki dampak positif karena dapat mengurangi biaya produksi untuk peternak.

Tabel 1. Nilai feed efficiency (\%) dan egg mass (g/ekor/hari) setelah perlakuan

\begin{tabular}{ccc}
\hline Perlakuan & $\begin{array}{c}\text { Rata-rata feed efficiency } \\
(\mathbf{g}) \pm \text { SD }\end{array}$ & $\begin{array}{c}\text { Egg mass } \\
(\text { g/ekor/hari }) \pm \text { SD }\end{array}$ \\
\hline P0 & $58.1^{\mathrm{a}} \pm 4.26$ & $46.4^{\mathrm{a}} \pm 4.93$ \\
P1 & $63.2^{\mathrm{b}} \pm 3.34$ & $51.9^{\mathrm{b}} \pm 3.36$ \\
P2 & $66.1^{\mathrm{b}} \pm 3.29$ & $47.9^{\mathrm{a}} \pm 2.02$ \\
\hline
\end{tabular}

Superskrip berbeda pada kolom yang sama menunjukkan perbedaan nyata $(p<0.05)$

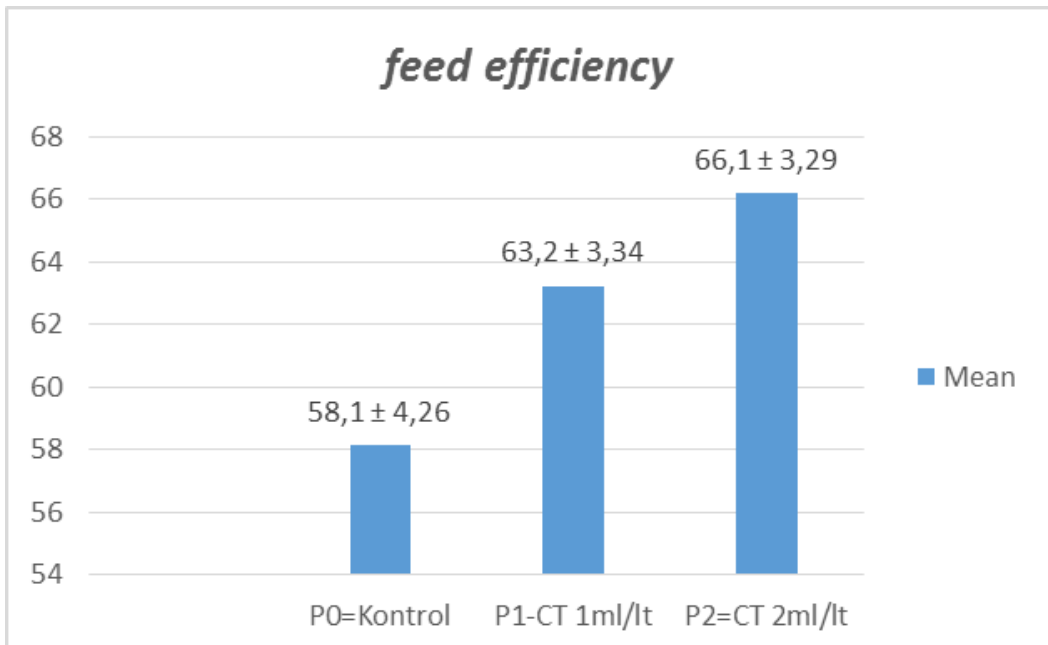

Gambar 1. Perbandingan rata-rata feed efficiency tiap perlakuan



Gambar 2. Perbandingan rata-rata egg mass tiap perlakuan 
Efisiensi pakan dipengaruhi oleh beberapa faktor, tidak hanya dipengaruhi faktor fisiologis dan genetik tetapi juga oleh mikrobiota usus. Mikrobiota di saluran usus bisa memengaruhi nutrisi pencernaan dan penyerapan energi. Peningkatan efisiensi pakan karena efek diberikan probiotik tambahan dapat dikaitkan dengan efek dari proses metabolisme pencernaan dan pemanfaatan nutrisi.Efek pemberian probiotik terhadap performa ayam petelur adalah dapat meningkatkan produksi telur karena probiotik yang bekerja di usus kecil dan usus besar dapat menekan bakteri patogen dan merangsang pertumbuhan dan aktivitas bakteri menguntungkan di usus yang dapat meningkatkan penyerapan nutrisi (Lokapirnasari et al., 2019). Peningkatan efisiensi pakan menunjukkan bahwa penyerapan nutrisi dilakukan secara optimal. Berat telur meningkat karena protein dalam pakan dapat diserap secara maksimal, dimana protein dan asam amino merupakan salah satu faktor penting yang dapat mempengaruhi berat telur. Semakin tinggi konsumsi protein, maka semakin tinggi pula produksi dan bobot telur (Maknun dkk., 2015).

Pada hasil egg mass, pemberian probiotik sebanyak $1 \mathrm{ml} /$ liter air minum (P1) berbeda nyata $(\mathrm{p}<0.05)$ dengan perlakuan yang diberikan probiotik sebanyak $2 \mathrm{ml} /$ liter air minum (P2) dan perlakuan yang tidak diberikan probiotik (P0). Pemberian probiotik sebanyak $2 \mathrm{ml} /$ liter air minum (P2) tidak berbeda nyata $(\mathrm{p}>0.05)$ dengan perlakuan yang tidak diberi probiotik (P0).

Rata-rata egg mass tertinggi terdapat pada perlakuan probiotik dengan konsentrasi $1.2 \times 10^{9}$ CFU/ml dosis $1 \mathrm{ml} /$ liter (P1) sebesar $51.9 \mathrm{~g} /$ hari (Gambar 2). Egg mass dalam penelitian tergolong cukup rendah. Hasil penelitian ini tidak sesuai dengan pernyataan ISA (2015) yang menyatakan standar nilai egg mass pada ayam petelur strain Isa brown umur 30 minggu adalah $59.7 \mathrm{~g} /$ hari. Faktor yang mempengaruhi egg mass adalah tingkat dewasa kelamin, protein dan asam amino yang cukup dalam pakan, genetik, tahap kedewasaan umur, obat-obatan dan zat-zat makanan dalam pakan (Yurlahmen, 2008). Menurunnya bobot telur dikarenakan terjadi defisiensi protein dan asam amino. Kualitas pakan yang rendah juga dapat menyebabkan ukuran kuning telur yang kecil sehingga berpengaruh terhadap berat telur. Aspek lain yang mempengaruhi masa telur adalah produksi pertama yang lebih rendah dibandingkan dengan produksi selanjutnya (Istinganah dkk., 2013).

Kelompok perlakuan yang diberikan tambahan probiotik pada air minum memberikan hasil yang baik jika dibandingkan dengan kelompok kontrol. Hasil penelitian tersebut sesuai dengan penelitian yang dilakukan oleh Pradikta dkk. (2018) bahwa nilai egg mass meningkat seiring bertambahnya probiotik yang diberikan untuk ayam petelur. Faktor utama yang dapat memberi pengaruh terhadap berat telur adalah kandungan protein dan asam amino pada pakan yang cukup besar, dimana sekitar 50\% dari bahan kering telur terdiri dari protein dan asam amino pada pakan (Istinganah dkk, 2013).

\section{KESIMPULAN}

Hasil dari penelitian yang telah dilakukan dapat disimpulkan bahwa pemberian probiotik yang mengandung Enterobacter sp., Cellulomonas sp., Actinomyces sp., Bacillus sp., dan Lactobacillus sp., dengan konsentrasi $1.2 \times 10^{9} \mathrm{CFU} / \mathrm{ml}$ dosis $1 \mathrm{ml} /$ liter dan $2 \mathrm{ml} / \mathrm{liter}$ dapat meningkatkan feed efficiency. Dosis 1 $\mathrm{ml} /$ liter memberikan hasil terbaik terhadap egg mass pada ayam petelur umur 30 minggu.

\section{UCAPAN TERIMA KASIH}

Penulis mengucapkan terima kasih kepada ayah dan ibu yang selalu memberikan motivasi. Teman-teman Pasca Sarjana Progam Studi Agribisnis Veteriner, Fakultas Kedokteran Hewan, Universitas Airlangga Surabaya angkatan 2018/2019 yang selalu memberikan semangat.

\section{DAFTAR PUSTAKA}

Badan Pusat Statistik (BPS). 2019. diakses dari http://www.bps.go.id/ 
Gallazzi, D., Giardini, A., Mangiagalli, G.M., Marelli, S., Ferrazzi, V., Orsi, C., Cavalchini, G.L. 2016. Effects Of Lactobacillus Acidophilus D2/Csl On Laying Hen Performance. Ital. J. Anim. Sci., 7, 27-37.

Hartono, M., Kurtini, T. 2017. Pengaruh Pemberian Probiotik Terhadap Performa Ayam Petelur. Jurnal Penelitian Pertanian Terapan, 15(3).

Diarmita, I.K. 2019. Kementan Dorong Peningkatan Ekspor Serta Konsumsi Protein Hewani Produk Ayam. Kemetrian pertanian Direktorat Jenderal Peternakan dan Kesehatan Hewan.

Dimyati, F. 2018. Prof Ning Iriyanti. Probiotik Alami solusi pengganti AGP. Poultry Indonesia.

ISA. 2015. Isa Brown Management Guide. A Hendrix genetics company.

Istinganah, L., Mugiyono, S., Iriyanti, N. 2013. Penggunaan berbagai jenis probiotik dalam ransum terhadap produksi dan bobot telur ayam arab. Jurnal Ilmiah Peternakan, 1(1), 338-346.

Lokapirnasari, W.P., Nazar, D.S., Nurhajati, T., Supranianondo, K., Yulianto, A.B. 2015. Production and assay of cellulolytic enzyme activity of Enterobacter cloacae WPL 214 isolated from bovine rumen fluid waste of Surabaya abbatoir, Indonesia. Vet. World, 8(3), 367.

Lokapirnasari, W.P., Dewi, A.R., Fathinah, A., Hidanah, S., Harijani, N., Soepranianondo, K., Andriani, A.D. 2018. Effect of Probiotic Containing Enterobacter Spp., Bacillus Spp., Cellulomonas Spp., Actinomyces Spp. Supplementation on The Laying
Performance and Egg Cholesterol of Quail. IOP Pub., 187(1), 012030.

Lokapirnasari, W.P., Sahidu, A.M., Maslachah, L., Supranianondo, K., Yulianto, A.B., Afikasari, D., Hariyati, I. 2018. In Vitro pH Tolerance, Bile Salt Resistance and Antimicrobial Activity of Lactobacillus plantarum Isolated from Crossbred Cattle. Philip. J. Vet. Med., 55(1), 73-78.

Lokapirnasari, W.P., Pribadi, T.B., Al Arif, A., Soeharsono, S., Hidanah, S., Harijani, N., Yulianto, A.B. 2019. Potency of probiotics Bifidobacterium spp. and Lactobacillus casei to improve growth performance and business analysis in organic laying hens. Vet. World, 12(6), 860.

Maknun, L., Sri, K., Isna, M. 2015. Performans produksi burung puyuh (Coturnix coturnix japonica) dengan perlakuan tepung limbah penetasan telur puyuh. Jurnal Ilmu-ilmu Peternakan, 25(3), 53-58.

Pradikta, R.W., Sjofjan, O., Djunaidi, I.H. 2018. Evaluasi penambahan probiotik (Lactobacillus sp.) cair dan padat dalam pakan terhadap penampilan produksi ayam petelur. Jurnal Ilmu-Ilmu Peternakan, 28(3): 203-212.

Ronstarci, T., Sjofjan, O., Djuaidi, I.H. 2015. Pengaruh Penambahan Probiotik Selulolitik (Cellulomonas sp) Dalam Pakan Terhadap Kualitas Karkas, Lemak Abdominal Dan Berat Organ Dalam Ayam Pedaging. Fapet. Ub. Ac. Id.

Yurlahmen, R. 2008. Performa Ayam Petelur Umur 21-27 Minggu Yang Diberi Air Rebusan Daun Sirih (Piper Bettle Linn) Pada Air Minum. Progam Studi Ilmu Nutrisi Dan Makanan Ternak Fakultas Peternakan IPB. Bogor. 